Chapman University

Chapman University Digital Commons

Pharmacy Faculty Articles and Research

School of Pharmacy

2010

\title{
Role of Transforming Growth Factor Beta in Corneal Function, Biology and Pathology
}

\author{
Ashish Tandon \\ Harry S. Truman Memorial Veterans' Hospital \\ Jonathan C. K. Tovey \\ Harry S. Truman Memorial Veterans' Hospital \\ Ajay Sharma \\ Chapman University, sharma@chapman.edu \\ Rangan Gupta \\ Harry S. Truman Memorial Veterans' Hospital \\ Rajiv R. Mohan \\ Harry S. Truman Memorial Veterans' Hospital
}

Follow this and additional works at: https://digitalcommons.chapman.edu/pharmacy_articles

Part of the Musculoskeletal, Neural, and Ocular Physiology Commons, Ophthalmology Commons, and the Other Pharmacy and Pharmaceutical Sciences Commons

\section{Recommended Citation}

Tandon A, Tovey JCK, Sharma A, Gupta R, Mohan RR. Role of transforming growth factor beta in corneal function, biology and pathology. Curr Mol Med. 2010;10(6):565-578.

This Article is brought to you for free and open access by the School of Pharmacy at Chapman University Digital Commons. It has been accepted for inclusion in Pharmacy Faculty Articles and Research by an authorized administrator of Chapman University Digital Commons. For more information,

please contact laughtin@chapman.edu. 


\section{Role of Transforming Growth Factor Beta in Corneal Function, Biology and Pathology}

\section{Comments}

This is a pre-copy-editing, author-produced PDF of an article accepted for publication in Current Molecular Medicine, volume 10, issue 6, in 2010 following peer review. The definitive publisher-authenticated version is available online at DOI: 10.2174/1566524011009060565.

\section{Copyright}

Bentham Science Publishers 


\title{
Role of transforming growth factor beta in corneal function, biology and pathology
}

\author{
Ashish Tandon ${ }^{1,2 A}$, Jonathan C. K. Tovey ${ }^{1,2 A}$, Ajay Sharma ${ }^{1,2 A}$, Rangan Gupta ${ }^{1,2 A}$, and \\ Rajiv R. Mohan ${ }^{1,2 A, B,{ }^{*}}$ \\ ${ }^{1}$ Harry S. Truman Memorial Veterans' Hospital, Columbia, MO 65201, USA \\ ${ }^{2 A}$ Mason Eye Institute, School of Medicine, University of Missouri, Columbia, MO 65212, USA \\ ${ }^{2 \mathrm{~B}}$ Department of Ophthalmology, College of Veterinary Medicine, University of Missouri, \\ Columbia, MO 65212, USA
}

\begin{abstract}
Transforming growth factor-beta (TGF $\beta$ ) is a pleiotropic multifunctional cytokine that regulates several essential cellular processes in many parts of the body including the cornea. Three isoforms of TGF $\beta$ are known in mammals and the human cornea expresses all of them. TGF $\beta 1$ has been shown to play a central role in scar formation in adult corneas whereas TGF 32 and TGF $\beta 3$ have been implicated to play a critical role in corneal development and scarless wound healing during embryogenesis. The biological effects of TGF $\beta$ in the cornea have been shown to follow SMAD dependent as well as SMAD-independent signaling pathways depending upon cellular responses and microenvironment. Corneal TGF $\beta$ expression is necessary for maintaining corneal integrity and corneal wound healing. On the other hand, TGF $\beta$ is perhaps the most important cytokine in the pathogenesis of fibrotic disease in the cornea. Although the transformation of keratocytes to myofibroblasts induced by TGF $\beta$ is largely believed to cause corneal fibrosis or scarring, the precise molecular mechanism(s) involved in this process is still unknown. Currently no drugs are available to treat corneal scarring effectively without causing significant side effects. Many approaches to treat TGF $\beta$-mediated corneal scarring are under investigation. These include blocking of TGF $\beta$, TGF $\beta$ receptor, TGF $\beta$ function and/or TGF $\beta$ maturation. Other strategies such as modulating keratocyte proliferation, apoptosis, transcription and DNA condensation are also being investigated. The potential of gene therapy to neutralize the pathologic effects of TGF $\beta$ has also been demonstrated recently.
\end{abstract}

\section{Keywords}

Cornea; gene therapy; corneal scarring/haze; TGF $\beta$

\section{INTRODUCTION}

Researchers discovered a new cytokine with the capability to transform fibroblasts in 1983 while studying epidermal and platelet derived growth factors in rat fibroblasts [1-2]. It has been almost three decades since transforming growth factor beta (TGF $\beta$ ) was characterized as a distinct molecular entity after isolation from bovine kidney, human placenta, and human

\footnotetext{
*Corresponding author: Rajiv R. Mohan, Ph. D., Mason Eye Institute, School of Medicine EC-210, University of MissouriColumbia, 1 Hospital Dr., Columbia, MO 65212, mohanr@ health.missouri.edu, Phone: (573) 884-1449, Fax: (573) 8146551. Commercial Relationship: A. Tandon, None; J.C.K. Tovey, None; A. Sharma, None; R. Gupta, None; R. R. Mohan, None.
} 
platelets. Originally called sarcoma growth factor, TGF $\beta$ was first isolated from neoplastic mouse tissue by Moloney sarcoma virus [3]. The TGF $\beta$ superfamily is made up of multifunctional cytokines that affect different cells and play a central role in wound healing and fibrosis of various organs including the cornea [4-5]. The TGF $\beta$ superfamily represents an extremely complex group of proteins in terms of structure, nomenclature, function, receptor types, sequence homology, and signaling pathways $[1,6]$. TGF $\beta$ proteins are found in scores of multicellular organisms in nature highlighting the importance of this cytokine family $[7,8]$. TGF $\beta$ elicits different responses depending on the context of action, concentration in different organs, and presence or absence of other growth factors influencing cellular and immunological activity.

The majority of cell types produce TGF $\beta$. TGF $\beta$ is initially formed as precursor TGF $\beta$ containing the latency-associated protein and the latent TGF-binding protein. The extracellular activation of this complex is crucial in TGF $\beta$-regulated biological activity. Upon activation, TGF $\beta$ transduces its signal through cooperative binding with two types of membrane bound TGF $\beta$ receptors and communicates the signals from the cell membrane to the nucleus via Smad-dependent or Smad-independent pathways [9]. The TGF $\beta$ superfamily includes three isoforms of TGF $\beta$, five activins, the Mullerian inhibiting substance, and eight or more bone morphogenetic proteins (BMP) encoded by different genes. TGF $\beta$ cytokines are involved in wound repair and many other vital pre- and postnatal physiological processes such as cellular proliferation, migration, differentiation, apoptosis, and extracellular matrix (ECM) production in various tissues including the cornea [10-12]. TGF $\beta$ is linked to a number of human diseases and pathological processes of many organ systems including autoimmune disease, oncogenesis, atherosclerosis, fibrosis of the lungs, liver, kidneys, and skin, and corneal scarring and dystrophy [13-16]. In this review, we will first discuss TGF $\beta$ isoforms, biosynthesis, maturation, signal transduction, and biological function. Then, we will discuss TGF $\beta$ 's role in corneal homeostasis and wound healing followed by its clinical significance in the pathogenesis of corneal disease and treatment approaches to control pathologic effects of TGF $\beta$.

\section{TGF $\beta$ ISOFORMS}

Five TGF $\beta$ isoforms have been identified in vertebrates. Three isoforms of TGF $\beta$ ( $\beta 1, \beta 2$, and $\beta 3$ ) have been identified in mammals while two additional isoforms have been reported, namely TGF $\beta 4$ and $\beta 5$ in birds and amphibians respectively [6,17-18]. All isoforms of mammalian TGF $\beta$ are $25 \mathrm{kDa}$ homodimeric proteins and share an extensive similarity in their amino acid sequences although subtle differences exist [19-20]. For instance, TGF $\beta 1$ shows $75 \%$ similarity to TGF $\beta 2$, and about $80 \%$ to TGF $\beta 3$ whereas TGF $\beta 2$ has approximately $80 \%$ similarity to TGF 33 [6]. Although these isoforms are homologues their amino acid sequences are encoded by three distinct genes suggesting that they may have different functions. First, the disulfide-linked functional protein, a monomer made up of two polypeptide chains, comes in either a homo- or heterodimer flavor. Second, the monomer is produced as the $\mathrm{C}$-terminal region of a precursor molecule that also houses a propeptide and a petite $\mathrm{N}$-terminal sequence required for secretion. Finally, all TGF $\beta$ superfamily members share a conserved C-terminal seven-cysteine domain as part of the monomer's primary structure essential for dimerization and protein stability [6].

TGF $\beta$ is ubiquitously expressed by many cell types such as fibroblasts, endothelium, epithelium, smooth muscle cells, etc. Moreover, it is released by immune cells and detected in wound fluid especially during inflammation and tissue repair. Although all three TGF $\beta$ isoforms participate in wound healing TGF $\beta 1$ plays a dominant role in the wound repair process while TGF $\beta 2$ and TGF 33 have been shown to play a key role in embryonic development and scarless wound healing [5,21-25]. 
The cornea and many other anterior eye segment tissues such as limbus, conjunctiva, and tear fluid have been shown to express different TGF $\beta$ isoforms and their receptors [26-27]. This insinuates the importance of the TGF $\beta$ in the eye as will be described later.

\section{TGF $\beta$ BIOSYNTHESIS AND MATURATION}

The biosynthesis and maturation of TGF $\beta$ is essential for its biological function. TGF $\beta$ is released as a large inactive precursor lacking the ability to bind to its cell surface receptors [28]. All three TGF $\beta$ isoforms have differences in precursor nucleotide sequence, precursor amino acid, gene location, and gene expression site as shown in Table (1).

The inactive TGF $\beta$ precursor consists of 390-442 amino acids with three specialized regions made up of an $\mathrm{N}$-terminal hydrophobic signal peptide region, the latency-associated peptide region of 249 amino acids, and the C-terminal region, a potentially bioactive TGF $\beta$ region consisting of 112 amino acids (Fig. (1)). The inactive TGF $\beta$ precursor is processed in the Golgi apparatus by endopeptidases, which cleave it at an $\mathrm{Arg}-\mathrm{X}-\mathrm{X}$-Arg site $(\mathrm{X}=$ any amino acid) leading to the formation of a small latent complex. This complex, which contains a mature TGF $\beta$ homodimer noncovalently attached to two latency-associated peptides, is usually secreted from the cell with latent TGF $\beta$ binding protein as the large latent complex [29]. Latent TGF $\beta$ binding protein anchors inactive TGF $\beta$ to the ECM requiring proteolytic cleavage for conversion to mature TGF $\beta$. Final activation of TGF $\beta$ involves the release of bioactive TGF $\beta$ from the latent complex via the interaction of latency-associated peptide with various proteins. Physical interactions with thrombospondin-1 or proteolytic cleavage brought about by plasmin, thrombin, endoglycosylase, or plasma transglutaminase causes a change in latency-associated peptide conformation liberating mature TGF $\beta$ [30] (Fig. (2)). In addition, recent studies evaluated the role of integrins in latent TGF $\beta$ activation and also showed both proteolytic and non-proteolytic (latent TGF $\beta$ conformational change via physical interaction) mechanisms [31].

Following the activation of bioactive TGF $\beta$, a $25 \mathrm{kDa}$ protein made up of two polypeptides of $12.5 \mathrm{kDa}$, signal transduction via different molecular signaling pathways may proceed.

\section{TGF $\beta$ SIGNAL TRANSDUCTION}

TGF $\beta$ functions as a regulatory cytokine and relays its commands from the cell surface to the nucleus by molecular signal transduction. Upon binding to cell-surface receptors, TGF $\beta$ ligands stimulate the assembly of serine/threonine kinase complexes which inaugurate signal transduction by cytoplasmic protein phosphorylation. This signal is then shuttled to the nucleus where it activates or suppresses target gene transcription leading to different cellular responses. The members of the TGF $\beta$ signal response incorporate Smad-dependent or Smadindependent signaling pathways depending on cell type.

\subsection{SMAD DEPENDENT SIGNALING}

Smad signaling pathway has been widely elucidated for the signaling of the TGF $\beta$ in regulating diverse cellular processes [5,25, and 33]. TGF $\beta$ transduces its signal across the plasma membrane by way of specific cell surface receptors known as TGF $\beta$ receptors [34]. Based on their structure, function, and electrophoretic mobility, the TGF $\beta$ receptor family is divided into three subfamilies: type I, II, and III receptors [1,6-7].

Type I receptors (TGF $\beta R 1$ ) have been found to have a higher level of sequence similarity than type II receptors (TGF $\beta$ R2), particularly in the kinase domain. TGF $\beta R 1$ and TGF $\beta$ R2 mainly affect the transduction of signals via serine-threonine membrane kinases that phosphorylate the hydroxyl site of serine-threonine on the target cell. Immediately upstream 
from its kinase domain, TGF $\beta$ R 1 has a conserved 30 amino acid region, the "juxtamembrane glycine-serine domain", which play important role in TGF $\beta R 1$ activation [35-36]. For phosphorylation, TGF $\beta$ R 1 requires activation by TGF $\beta R 2$ to trigger its kinase function whereas TGF $\beta R 2$ boasts intrinsic kinase activity. Furthermore, TGF $\beta R 1$ requires TGF $\beta R 2$ for ligand binding [37-38]. After phosphorylation, TGF $\beta R 1$ phosphorylates and activates the highly-conserved cytoplasmic proteins of the Smad family. Besides TGF $\beta$ R 1 and TGF $\beta R 2$, a third TGF $\beta$ receptor also exists. TGF $\beta$ receptor III (TGF $\beta$ R3) is a transmembrane proteoglycan also known as betaglycan [39]. TGF $\beta$ R3 binds to all three mammalian isoforms via its core protein and has a molecular weight ranging from 250-300 $\mathrm{kDa}$. Betaglycan has been reported to be a mixture of heparan sulfate and chondroitin sulfate glycosaminoglycan [40,41]. Along with endoglin, it is found to have the unique property of binding TGF $\beta$ with high affinity. There is also evidence that the highest level of sequence similarity between betaglycan and endoglin is found in the cytoplasmic and transmembrane domains [42].

Previously Cheiftz and collaborators evaluated the ligand binding property of betaglycan and its presence in serum and ECM [18]. Many studies have revealed that TGF $\beta$ R3 is not directly involved in TGF $\beta$ signal transduction. However, after binding to various TGF $\beta$ superfamily members at the cell surface, it may act as a ligand reservoir for TGF $\beta$ receptors. Therefore, even though TGF $\beta R 3$ is not believed to take part in signal transduction directly, it allows high affinity binding to TGF $\beta$ R2. TGF $\beta 1$ and $\beta 3$ bind TGF $\beta R 2$ to initiate signal transduction whereas TGF $\beta 2$ requires TGF $\beta R 3$ in order to bind TGF $\beta R 2$ [43]. Upon binding to its corresponding receptor, TGF $\beta$ elicits its signals through Smad transducers (Fig. (3)).

What are SMADS?-SMADs are evolutionarily conserved proteins that modulate the activity of the large family of proteins related to TGF $\beta$. Smad proteins, the only substrates for type I receptor kinases, were first identified as the gene products of Drosophila melanogaster Mad and Caenorhabditis elegans Sma genes. The term Smad was thus derived from Sma and Mad (Mothers against decapentaplegic) gene homologues in C. elegans and D. melanogaster $[44,45]$. The Smad family is classified according to function and consists of three main categories. These include receptor-regulated Smads (R-Smads), common mediator Smads (co-Smads), and inhibitory Smads (I-Smads). R-Smads (Smads1-3, Smad5, and Smad8) are ligand specific and become phosphorylated after directly interacting with activated TGF $\beta R 1$. The receptor regulated Smads, Smad2 and Smad3, are mainly phosphorylated by TGF $\beta$ cytokines and activin receptors while Smad1, Smad5, and Smad8 are phosphorylated by BMP receptors [46]. Smad4, a co-Smad, is a common intermediary of all TGF $\beta$ superfamily members including TGF $\beta$, activins, and BMP receptors for signal transduction from cell membrane to the nucleus. Furthermore Smad4 is essential for nucleus entry by associating with a receptor phosphorylated R-Smad. Finally, the third group comprises I-Smads also termed anti-Smads. I-Smads, Smad6 and Smad7, antagonize TGF $\beta$ signaling by interfering with the activation of R-Smads [47]. It has also been clearly noted that I-Smads demonstrate their action by associating with TGF $\beta$ R 1 and for the most part inhibit R-Smad recruitment by phosphorylation. In differentiating between the I-Smads, it has been reported that Smad7 mainly inhibits TGF $\beta$ and activin signaling while Smad6 inhibits BMP signaling in different cellular processes. Generally, Smads remain in their basal state in the cytoplasm to allow for their timely exposure to activated receptors. Besides this, type E3 ubiquitin ligases known as Smad ubiquitination regulatory factors-1/2 (Smurf-1/2), are also important in the regulation of different TGF $\beta$ signaling pathways [48]. By and large Smurf-1/2 targets TGF $\beta R 1$, TGF $\beta$ R2, and various Smads for proteasomemediated degradation.

Structurally Smads are characterized by two highly conserved proline-rich globular domains, N-terminal Mad homology 1 (MH-1) and C-terminal Mad homology 2 (MH-2), 
that are held together by a nonconserved variable linker region. The MH1 domain recognizes the DNA sequence CAGAC whereas the MH2 domain mainly binds transcriptional coactivators.

The MH-1 and MH-2 domains of R-Smads and co-Smads show conserved regions as does the MH-2 domain of I-Smads. The MH-1 domain of I-Smads however, is not conserved and shows variation among species. Variability also exists in the functions of different $\mathrm{MH}-1$ and MH-2 domains. For instance, the MH-1 domain of R-Smads binds DNA, while the MH-2 domain participates in intermolecular protein-protein interactions and is responsible for activating transcription. Moreover, studies have shown that the MH-1 domain of Smad3 and Smad4 possesses DNA binding ability whereas Smad2's MH-1 domain does not directly bind to DNA efficiently [49-50]. Vasaliki and cohorts recently showed that amino acids glutamine 222 and proline 229 of the conserved variable linker region of Smad proteins plays principle roles in homo- as well as hetero-oligomerization and nuclear accumulation [51]. At the extreme C-terminus of the $\mathrm{MH}-2$ domain, $\mathrm{R}-\mathrm{Smads}$ contain a phosphorylation motif, SSxS, which is the site of Smad2 and Smad3 phosphorylation by TGFßR1 (Fig. (4)). Specifically, the last two Ser residues of the C-terminal SSxS motif are important and provide the site for the phosphorylation of R-Smads [52].

The activated TGF $\beta R 1$ then specifically recognizes and phosphorylates R-Smads, recruited by Smad anchor for receptor activation (SARA) that presents R-Smads as substrates to the activated TGF $\beta$ receptor complex. R-Smad phosphorylation decreases its affinity for SARA and leads to the formation of a heterocomplex with the unique co-Smad, Smad4. The activated R-Smads form a heterotrimeric complex with Smad4, and are then rapidly translocated to the nucleus. Smad4 translocates to the nucleus only when combined with RSmads unlike R-Smads which may autonomously enter the nucleus from the cytoplasm without Smad4. When Smad4 is blocked or absent however, R-Smads may translocate but lack the ability to complete the signal to the nucleus via gene expression. This finding suggests that the main role of Smad4 is to regulate transcription rather than to transmit TGF $\beta$ signals from the cytoplasm to the nucleus. In many ways, the Smad heterotrimeric complex is viewed as a coactivator for various transcription factors. This is because it activates or suppresses transcription by way of its interactions with coactivators CBP/p300 [53-54]. After entrance into the nucleus, the complex interacts at the promoter site with transcription factors that contain sequence-specific DNA binding affinity to regulate gene expression. Here the heterotrimeric complexes essentially activate downstream responses and may act as transcriptional factors themselves controlled by a balance between transcriptional co-activators and co-repressors. In short, the heterotrimeric complex may recruit co-activators to stimulate transcription or recruit co-repressors to inhibit transcription leading to the expression of genes responsible for different cellular responses.

\subsection{SMAD INDEPENDENT SIGNALING PATHWAY}

Accumulating evidence over the past few years indicates that TGF $\beta$ may signal through several pathways besides the Smad cascade for modulation of cell activity during both embryonic development and corneal wound healing. One such study conducted by the Saika group (2004) reported a lack of Smad3/4 localization in the nuclei of migrating corneal epithelium showing that the TGF $\beta / S m a d$ pathway may not be directly involved in the regulation of cell proliferation. This is evident by the fact that TGF $\beta$ can activate several mitogen-activated protein kinases (MAPKs), including extracellular signal-regulated kinases (ERKs), c-Jun N-terminal kinases (JNKs), and p38 kinases [55-56]. TGF $\beta$ also activates the phosphatidylinositol-3 kinase (PI-3) pathway, and in certain cells, signaling involving PP2Aphosphatase and RhoA (Fig. (5)). The MAPK signaling cassette is composed of the ERK, p38, and JNK/SAPK pathways which operate in parallel with one another. The 
MAPK pathways in mouse, rabbit, and human corneal epithelium mediate cell migration of corneal epithelium [57].

\section{TGF $\beta$ BIOLOGICAL FUNCTION}

TGF $\beta$ affects a vast range of biological processes. It regulates cell replication, proliferation, differentiation, and migration [32,58, and 59]. TGF $\beta$ also controls cell cycle progression, programmed cell death, ECM production, immune tolerance, inflammation, angiogenesis, hematopoiesis, bone formation, wound healing, and fibrosis [60-62]. In addition, TGF $\beta$ stimulates collagen synthesis and the production of several key proteins such as tenascins, fibronectin, thrombospondin, proteoglycans, tissue inhibitor of metalloprotease-1 (TIMP-1), and plasminogen activator inhibitor-1 (PAI-1) [10,63]. Furthermore, TGF $\beta$ is known to act in an isoform-dependent way to protect neurons. In many instances TGF $\beta$ has two-way functional capabilities allowing it to inhibit various cellular processes in one context while stimulating the same processes in another. For example, TGF $\beta$ functions as both a stimulator and inhibitor of cellular replication thus controlling ECM production [64]. As is evident, TGF $\beta$ has various effects in different cells in diverse settings. It is essential for the maintenance of life (tissue homeostasis) as it mediates tissue growth and development as well as tissue wound healing following injury. Overexpression of this vital growth factor however, may lead to disease and in some instances, death.

\subsection{TGF $\beta$ 'S ROLE IN FIBROSIS AND OTHER DISEASES}

Following an injury, the body expends a great deal of energy in an effort to repair itself and restore tissue function. This leads to healing via a fibroproliferative response which entails TGF $\beta$-mediated deposition of excessive collagen along with ECM. This type of wound healing involves inflammation, angiogenesis, migration and proliferation of fibroblasts, and connective tissue remodeling that leads to scarring. Previous studies have identified TGF $\beta 1$ and TGF $\beta 2$ as potent stimulators of fibrosis in the skin [65-66]. After sustaining an injury, TGF $\beta$ regulates damage repair and endeavors to restore previous tissue function and morphology. This maintenance of tissue homeostasis involves delicate interactions among TGF $\beta$, the ECM, and different cells. This restores vital barrier function, integrity, and tensile strength of the tissue [67-69]. Unlike adult tissue, fetal tissue exhibits the ability to swiftly heal skin wounds and render them scar free. This is thought to be due to several mechanistic differences that exist between fetal and adult wound healing as well as TGF $\beta$ levels $[66,70]$. For instance, adult tissue is contaminated and desiccated while fetal tissue is surrounded by amniotic fluid and is housed in a germ-free environment. Additionally, adult tissue is fully differentiated and fibroblast migration along with reepithelialization occurs at a much slower rate than in fetal tissue. Furthermore, in adult wounds there is a massive inflammatory response compared with fetal wounds. Potent platelet degranulation of active cytokines, especially TGF $\beta$, is also visible in adult wounds while a reduced amount is seen in fetal wounds [71]. In regards to specific TGF $\beta$ isoforms, TGF $\beta 3$ has been shown to predominate in fetal wound healing where TGF $\beta$ action is modulated by fibromodulin. However, this is not the case in adults as TGF $\beta 1$ is the chief isoform and is modulated by proteoglycans including decorin. This suggests that scarless wound healing may be influenced by the relative ratio of different TGF $\beta$ isoforms in particular TGF $\beta 1$ and $\beta 3$ [72]. Past studies have also found that the addition of exogenous TGF $\beta$ to fetal wounds switches the scarless tissue regeneration healing process to adult-like wound healing where scarring results [30,73]. This also reemphasizes the importance of various isoforms of TGF $\beta$ in homeostasis, wound repair, and fibrosis.

The disturbance of TGF $\beta$ homeostasis may result in various pathological entities including fibrosis. TGF $\beta$ deficiency has been linked with defective wound repair, as well as 
autoimmune diseases, inflammation, atherosclerosis, and oncogenesis. Excessive TGF $\beta$ levels have been associated with hypertension, angiogenesis, and cancer [74].

TGF $\beta$ has bidirectional capabilities that are very much context specific. In various physiologic and disease states, it may function as an inhibitor of various cellular processes in one instance but promote the same processes in another. In the immune system for example, TGF $\beta$ regulates leukocyte activation along with chemotaxis. By so doing, it protects the body from the development of autoimmune diseases while allowing the immune system to combat foreign pathogens. If TGF $\beta$ is overexpressed however, immunopathologies such as cancer may result. Early in oncogenesis, TGF $\beta$ operates as an anti-mitogenic factor and a tumor suppressor [75]. Later on as the cancer progresses however, the once-protective cytokine promotes angiogenesis as well as myofibroblast transformation furthering tumor expansion, advancement, and metastasis [76]. In other systems, an increase or decrease in TGF $\beta$ may lead to disease in both cases. This is seen in chronic obstructive pulmonary disease where overactive TGF $\beta$ signaling leads to small airway disease while decreased TGF $\beta$ signaling triggers parenchymal tissue obliteration in emphysema [77]. We, along with others, speculate that assorted gene transcription regulation is thought to be the avenue by which TGF $\beta$ exerts contradictory effects.

As discussed earlier, TGF $\beta$ also directs ECM production as it is a stimulator and inhibitor of cell replication [64]. TGF $\beta$ stimulates the synthesis of collagens, fibronectin, proteoglycans, thrombospondin, PAI-1 and TIMP-1. The increased secretion of PAI-1 and MMP-9 brought about by TGF $\beta 2$ has been shown to play a role in prostate cancer where TGF $\beta$ mainly induces apoptosis of the epithelium. In the developing embryo TGF $\beta$ has been reported to be a powerful inhibitor of hematopoietic stem cell proliferation. Nevertheless, its role in adult hematopoiesis has yet to be elucidated. The role of TGF $\beta$ superfamily in myocardial infarction including infarct healing, cardiac repair, and remodeling has also been reported although the molecular mechanism is still unknown [78].

\subsection{TGF $\beta$ EXPRESSION AND LOCALIZATION IN THE CORNEA}

TGF $\beta$ is expressed in the cornea reflecting its complex role in maintaining corneal integrity and promoting corneal wound healing [79-80]. The cornea, a transparent avascular tissue that covers and protects the front surface of the eye, is made up of three cell layers and two membranes from anterior to posterior: epithelium, epithelial basement membrane (Bowman's layer), stroma, Descemet's membrane, and endothelium. Although constitutively expressed by the uninjured cornea, TGF $\beta$ has been reported in varying quantities in different layers of the cornea depending on the condition of the cornea [80]. For example, TGF $\beta$ is normally restricted to healthy intact corneal epithelium but is secreted into the stroma during wound healing [81]. In the healthy cornea TGF $\beta 1$ is detected inside epithelial cells while the isoforms TGF $\beta 2$ and $\beta 3$ are present in the extracellular environment [15]. In the wounded cornea TGF $\beta 1$ is the minor isoform observed while TGF 2 , the major mediator of the corneal fibrotic response, is detected in large amounts.

Previous studies report that both TGF $\beta 1$ and $\beta 2$ are seen within the corneal epithelium and stroma in the injured cornea while TGF $\beta 3$ is not found in the anterior eye at all $[12,82-83]$. Recently however, Huh and colleagues reported unique differences in isoform expression including TGF $\beta 3$ following corneal wounding in chick cornea via immunohistochemistry. TGF $\beta 3$ was found in basal cells of regenerating areas as well as uninjured regions of the cornea after corneal injury while TGF $\beta 1$ levels were increased in Bowman's layer and TGF 32 demonstrated strong expression in migrating and proliferating epithelial cells, fibroblasts, Descemet's membrane, and the endothelium [80]. Other investigators also hold that all three isoforms occur after corneal injury and are present in the stroma. Variation in TGF $\beta$ corneal expression also exists among species. For example, TGF $\beta 1$ was observed in 
normal chick cornea but was absent in normal and wounded mice corneal epithelium. This could be due to differences in corneal composition as mice lack Bowman's layer in the cornea [84].

From clinical observation and extensive experimentation, we and other researchers have postulated that the integrity of Bowman's layer may play a key part in TGF $\beta$ release from the corneal stroma in corneal wound healing. Upon debriding the corneal epithelium from Bowman's layer, cells of the corneal stroma undergo programmed cell death and the stroma is regenerated via mitosis. This occurs without the hypercellularity and excess ECM deposition seen in fibrosis as will be discussed in following sections. The expression of fibrotic markers is observed only if Bowman's layer is penetrated and the stroma is ablated after debridement of the corneal epithelium as seen in photorefractive keratectomy (PRK). Laser-assisted in situ keratomileusis (LASIK) takes advantage of this fact as Bowman's layer is only pierced around the borders of a flap. This allows for replacement of dead keratocytes surrounding the ablated area without stimulating the fibrotic response leading to subsequent corneal haze $[81,85]$. A recent study conducted by our lab sought to observe systematic and time-dependent monitoring of TGF $\beta$ following injury using a PRK rabbit model. Fig. (6) shows time-dependent localization and levels of TGF $\beta 1$ in -9.0 D PRKtreated rabbit cornea. PRK caused a significant increase in TGF $\beta 1$ in the stroma from day-1 to day-3. The increase in TGF $\beta 1$ expression at day 1 and day 3 in the stroma of post-PRK cornea was found statistically significant $(\mathrm{p}<0.001$ or $<0.01)$ compared to naïve corneas. Nonetheless, a decline in an elevated level of TGF $\beta 1$ was observed after these two time points as extremely low or no TGF $\beta 1$ expression was detected at day 7 or day 14 in the stroma. As expected TGF $\beta 1$ expression was observed in the regenerated epithelium and basement membrane, which was removed prior to performing PRK. The levels of TGF $\beta 2$ expression in the rabbit stroma after PRK injury was markedly different from the TGF $\beta 1$, however, the pattern of change in expression level was similar but not identical as evident from Fig. (7). Like TGF $\beta 1$, the TGF $\beta 2$ levels in the anterior stroma at day 1 and day 3 after PRK was significantly $(\mathrm{p}<0.01)$ higher than the naïve controls. This strongly suggests that TGF $\beta$ is essential in initiating the corneal wound healing response and once activated, the response may prove self-perpetuating.

All three isoforms are found in different regions of the cornea reflecting their different roles. Jester and colleagues previously showed the role of TGF $\beta 1$ following refractive surgery in keratocyte activation, myofibroblast transformation and proliferation, and wound healing [86]. TGF $\beta 2$ plays a key role in corneal development (epithelial-mesenchymal interactions) as well as homeostasis and repair [87]. Following corneal wounding for example, TGF $\beta 2$ is detectable in the central corneal wound region where it is responsible for myofibroblast transformation, proliferation and stratification that leads to regeneration of corneal epithelial cells. The mechanism by which this occurs includes migration of activated keratocytes at the wound edge into the fibrin clot which is largely replaced by fibroblasts that become TGF $\beta 2$ producing myofibroblasts. Along with TGF $\beta 1$ and TGF $\beta 2$, TGF $\beta 3$ also stimulates epithelial cell proliferation in the cornea especially in unwounded regions [80].

\subsection{TGF $\beta$ 'S ROLE IN CORNEAL WOUND HEALING AND SCARRING}

Wound healing plays an integral part in the maintenance of corneal transparency and is thus crucial to normal visual function [25]. Corneal injury has been shown to trigger an unfettered wound healing response that all but induces scarring leading to visual loss. Corneal scarring is an important ocular pathology and is the third leading cause of blindness worldwide [88]. Numerous growth factors and cytokines have been found to regulate corneal wound healing and include TGF $\beta$, connective tissue growth factor, ECM, distinct cell types, etc. TGF $\beta$ is arguably the most important ligand in the pathogenesis of fibrotic disease in the cornea as well as in the eye as a whole. Examples range from corneal scarring 
to lens capsule fibrosis following cataract surgery to tractional retinal detachment in proliferative diabetic retinopathy [25]. In addition to being a sequela of corneal infection, TGFß-mediated corneal haze development is also apparent following surgical procedures such as PRK, a common laser eye surgery used globally to correct refractive errors in humans $[4,89]$. As shown in Fig (6) and (7), TGF $\beta 1$ and TGF $\beta 2$ detected immediately following PRK injury affect keratocyte, fibroblast, and myofibroblast population in the corneal stroma. This strongly suggests that TGF $\beta$ is essential in initiating the corneal wound healing response and once activated, the response may prove self-perpetuating.

It has been reported that following corneal injury, TGF $\beta$ overexpression leads to corneal turbidity. This is because increased TGF $\beta$ levels augment JNK 1/2-mediated connective tissue growth factor gene expression. Proliferation and migration of ECM proteins collagen and fibronectin by corneal fibroblasts ensues leading to corneal haze [90]. Specifically, the release of TGF $\beta$ from injured corneal epithelium induces transformation of quiescent keratocytes into corneal fibroblasts and myofibroblasts, a molecular mechanism known to cause haze. Myofibroblasts are metabolically active and highly contractile cells with reduced transparency attributable to decreased intracellular crystallin production [89].

To date, numerous efforts have been made to identify the mechanism for the effect of TGF $\beta$ on improving healing wounds and epithelialization. Following corneal injury, TGF $\beta$ leads to an increase in pro-fibrotic molecules and cytokines that control the immune response as well as inflammation. In particular, TGF $\beta$ affects chemotaxis of pro-inflammatory cells such as monocytes, lymphocytes, neutrophils, and fibroblasts as well as the production and remodeling of ECM, mitosis induction in certain fibroblasts, and angiogenesis [76,91]. Once fibroblasts commence the proliferation process, collagen production is increased. The amplified production of collagen coupled with decreased ECM degradation leads to an increase in scar formation [92].

TGF $\beta 1$ is responsible for myofibroblastic differentiation, the transdifferentiation of quiescent keratocytes to fibroblasts and myofibroblasts seen in corneal fibrotic disease alluded to earlier. Myofibroblast transformation leads to wound contraction and subsequent aberrant tissue function. Myofibroblasts, which originate from mesenchymal cells or epithelial cells via epithelial-mesenchymal transition, can be distinguished by the expression of $\alpha$-smooth muscle actin ( $\alpha$-SMA) and alter ECM production in corneal wound healing. Biochemically and morphologically an intermediate between smooth muscle cells and fibroblasts, myofibroblasts generate a powerful contractile force, essential to wound closure. Myofibroblastic differentiation brought about by TGF $\beta 1$ is often accompanied by gene expression augmentations of essential wound healing proteins. Examples include cytoskeletal proteins ( $\alpha$-SMA), ECM proteins (fibronectin, proteoglycans, and collagen), and inhibitory proteins that deter ECM degradation. Additionally, myofibroblastic transformation leads to the loss of cell-cell contact between fibroblasts in cell cultures [93].

TGF $\beta$ in other areas of the eye in close proximity to the cornea affects corneal scarring. A recent study showed that increased expression of TGF $\beta 1$ in the anterior chamber leads to myofibroblast transformation in all corneal layers. The loss of corneal homeostasis due to endothelial damage following injury or surgery deep to the cornea may also play a role in corneal fibrosis and subsequent corneal opacification. In addition to the aqueous humor in the anterior chamber, the cornea is also in direct contact with the tear film suggesting that TGF $\beta$ and other cytokines and growth factors present in this layer also influence corneal wound healing [23]. 


\section{CURRENT AND FUTURE TREATMENTS TARGETING TGF $\beta$}

TGF $\beta$ superfamily members have been implicated in various biological and pathological processes. Thus corneal haze is a result of TGF $\beta$-modulated wound healing following ocular infection or trauma including injury and surgery. Current conventional small molecule drug treatments do not effectively treat corneal scarring and angiogenesis, require repeated drug application and are associated with side effects. On the horizon, other novel approaches such as gene therapy are proving to have potential in corneal haze treatment. It is also thought that the timing of therapy is critical as early treatment is imperative to prevent corneal scarring. Ongoing experiments in our laboratory are focused on the suppressor functions of TGF $\beta 1$, a potential strategy to treat corneal scarring, and aim to elucidate the unique molecular mechanisms underlying the role of this vital cytokine in wound healing for corneal eye disease.

Presently no effective remedy exists to eliminate corneal scarring without significant adverse effects. Although topical corticosteroids are frequently utilized in the treatment of corneal scarring, they are only beneficial short-term, cause many side effects, and seldom prove efficacious in reducing corneal scarring [94]. Numerous corneal surgeons apply topical mitomycin C (MMC) prior to PRK to avert laser-induced corneal haze. MMC, an alkylating chemotherapeutic agent, attempts to limit corneal haze by blocking proliferation brought about by TGF $\beta$. However, MMC causes several complications such as corneal endothelial damage, abnormal wound healing, limbal and scleral necrosis, and loss of keratocytes [95-96]. Netto and colleagues recently demonstrated that topical application of MMC also inhibits repopulation of keratocytes and establishes an acellular zone in rabbit corneas up to six months post application [97].

Several other agents such as synthetic inhibitors of metalloproteinase, cyclosporine-A, vitamin E, diclofenac, etc. have shown some benefit in animal studies. However, their high toxicity combined with other deleterious side effects limit their use in humans [98-100]. Nerve growth factor and amniotic membrane have also been reported to control corneal scar and corneal ulcer formation. Even so, clinical trials with nerve growth factor failed to show significant benefits compared to conventional treatment (tarsorrhaphy or bandage contact lens) [101-102]. Phototherapeutic keratectomy, a laser surgical technique, has also been used to treat corneal scarring resulting from gunpowder explosion but leads to undesirable side effects including hyperopic shift and astigmatism among others. The complications and, in some cases, toxicity of current practices in the management of corneal scarring illustrates the inherent risks of these treatments and advocates for the development of safer, improved pharmacologic agents in reducing corneal haze without serious side effects [98-100].

We recently tested our hypothesis that agents having inactivation as well as neutralization properties of TGF $\beta$ can inhibit haze progression in the cornea in vivo. We reported that trichostatin A (TSA), a histone deacetylase inhibitor that suppresses TGF $\beta$-induced fibrogenesis in many nonocular tissues, reduces corneal haze [103]. Although not currently in clinical use, TSA may be incorporated into treatment of ophthalmology patients to reduce corneal haze in the near future. In addition to TSA, our laboratory also studied vorinostat, an FDA-approved derivative of TSA presently in clinical use for the treatment of progressive, persistent, or recurrent cutaneous T-cell lymphoma. In preliminary experiments, vorinostat showed similar potential to TSA in impeding corneal haze development $\left.{ }^{\mathrm{a}}\right]$. Besides vorinostat, moxifloxacin has been shown to inhibit myofibroblast development by blocking TGFßRI [b].

aLopez, V., Tovey, J., Sharma, A., Waggoner, M., Cowden, J.W. and Mohan, R.R. Vorinostat Effectively Reduces TGFß-Mediated Myofibroblast Formation in the Cornea. Program Summary of ARVO 2010 Meeting, Fort Lauderdale, Florida, May 2-16, 2010 ; p. 57. 
The feasibility of treating corneal scarring via gene therapy, an innovative treatment modality approach, has also been demonstrated [104]. Gene therapy in the cornea seeks to employ appropriate vectors (viral or non-viral) to transfer genes to the cornea in order to increase or decrease the expression of a particular protein, cytokine, or growth factor that will in turn modulate corneal disease. In the case of corneal scarring, the cytokine of concern is none other than TGF $\beta$. We conjecture that genes blocking TGF $\beta$ activity will prevent myofibroblast transformation and thus scarring in the cornea in vivo. We recently demonstrated inhibition of TGF $\beta$-mediated transdifferentiation of corneal keratocytes to myofibroblasts with decorin, a natural modulator of TGF $\beta$, using an in vitro model. In our study we demonstrated the presence of decorin mRNA and protein in rabbit cornea. Studies in non-ocular tissues have demonstrated that collagen-bound decorin does not efficiently neutralize TGF $\beta$. Since decorin in the cornea is bound to collagen, it may not be available to neutralize PRK-induced increased TGF $\beta$ levels in the corneal stroma. Therefore, PRKinduced corneal haze may represent an imbalance between TGF $\beta$ and its endogenous inhibitor decorin [105]. Another approach that has been tested in preventing corneal scarring is the blockade of cyclins and cyclin-dependent kinases, both of which play an active role in controlling cell division. Further studies are needed to delineate the utility of decorin in treating corneal scarring.

Other avenues in gene therapy endeavor to block certain targets in the TGF $\beta$ signaling pathway. In this manner, beneficial effects of TGF $\beta$ such as JNK-dependent fibronectinmediated epithelialization of wounds are preserved while detrimental effects of TGF $\beta$ such as Smad3-induced collagen overproduction are inhibited. Examples include blocking specific R-Smads, such as Smad3. In wound healing experiments, it was found that the overexpression of I-Smads, like Smad7, had similar effects to blocking Smad3 in reducing TGF 31 gene expression. In addition to its effects in the cytoplasm, Smad7 may block transcription factors in the nucleus. Major advantages of gene therapy include lower dose for effect, lower cost, increased efficiency, and a longer period of gene expression eliminating the need for frequent repeated injections or applications which can further hamper wound healing. A concern with gene therapy however, is possible harmful side effects. Although gene transfer with viral vectors may result in a secondary inflammatory reaction, this can be circumvented with the utilization of non-viral vectors like plasmid DNA [92].

Another approach in gene therapy for corneal scarring is the use of soluble TGF $\beta$ R2. Soluble TGF $\beta$ R 2 blocks TGF $\beta$ activity by binding TGF $\beta$ thus rendering it unable to bind its cell surface receptor. In corneal injury model, a single dose of recombinant adenovirus encoding for soluble TGF $\beta$ R2 decreased corneal opacification as well as inflammation, and neovascularization [104]. Unfortunately, like other gene therapy methods, this approach is unregulated and untargeted leading to numerous adverse effects. Although these examples show the potential of gene therapy in treating corneal scarring, they also point out major obstacles, like safety profile, that need to be addressed if gene therapy is to make the transition from the laboratory to clinical practice in patients. Our lab is working to optimize tissue-selective targeted gene delivery into keratocytes employing AAV vectors that are non-pathogenic to humans. With the utilization of a specific mutant vector and specialized surgical techniques, we have demonstrated successful transduction of genes into the corneal endothelium.

On the protein level, TGF $\beta$ antagonists such as monoclonal antibodies are also showing promise in treating corneal scarring. Earlier, Shah and collaborators reported results from a ground-breaking study where anti-TGF $\beta 1$ and $\beta 2$ antibodies were shown to inhibit

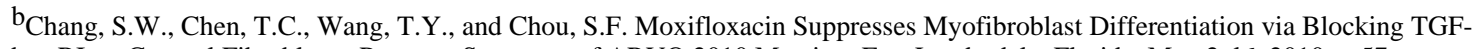
betaRI on Corneal Fibroblasts. Program Summary of ARVO 2010 Meeting, Fort Lauderdale, Florida, May 2-16, 2010; p 57. 
formation of cutaneous scars in rodent wounds. Not only did the antibody-treated wounds demonstrate decreased TGF $\beta 1$, collagen, and fibronectin levels, they also showed an increase in normal cutaneous structure, and equal tensile strength as compared to other wounds. A follow up study where TGF $\beta 3$ was added to the wounds also showed decreased cutaneous scarring [106]. Furthermore, it was established by the same group that early treatment is paramount in decreasing scar formation as the first dose of TGF $\beta$ stimulates TGF $\beta$ overproduction. This comes about by way of chemotaxis and autoinduction which in turn induces collagen overproduction and fibroblast proliferation while simultaneously inhibiting ECM breakdown [92].

Carrington and cohorts found that in the cornea TGF $\beta 1$ delays re-epithelialization, accelerates keratocyte proliferation, increases repopulation of cells around the wound, and encourages the transformation of keratocytes to myofibroblasts [107]. In contrast, they also found that the anti-TGF $\beta 1$ monoclonal antibody CAT-192 enhances re-epithelialization of the cornea while reducing stromal repopulation. Comparable results to CAT-192 were also reported with low doses of IL-10 and exogenous TGF $\beta 3$, although TGF $\beta 3$ elicited little effect on corneal re-epithelialization. This recognizes IL-10 and TGF $\beta 3$ as potential agents in treating and preventing fibrosis in the cornea [107]. Although monoclonal antibodies may seem to be an optimum treatment choice for corneal scarring, a major problem accompanying their use is their stability at room temperature. In addition to monoclonal antibodies, treatment for corneal scarring on the protein level includes biglycan as well as soluble TGF $\beta$ receptors and decorin as explained above [96].

Another approach to thwart the effects of TGF $\beta$ may be to block its maturation from latent TGF $\beta$. Zieske and cohorts demonstrated in a mouse model that $\alpha \mathrm{V} \beta 6$ integrin, a key protein involved in latent TGF $\beta 1$ activation by latent-associated peptide cleavage, is increased during epithelial wound healing. A significant reduction in laminin, $\alpha$-SMA, and mature TGF $\beta 1$ was seen as well as an increase in large latent TGF $\beta 1$ in $\beta 6$-null mice following keratectomy. This is another strategy where TGF $\beta$ modulation can be achieved $\left[{ }^{\mathrm{C}}\right]$.

Corneal wound healing, mediated by various cytokines such as TGF $\beta$, necessitates functioning stem cells from the adjacent corneoscleral junction also known as the limbus. The loss of these vital stem cells consequently leads to wound healing difficulties. Although not well characterized, several signaling pathways including TGF $\beta$ control corneal stem cells. Limbal stem cells have successfully been used in human autograft transplantation in the past. For example, one study demonstrated that limbal explants containing limbal epithelial stem cells obtained from the healthy eye of an individual could be transplanted into the contralateral diseased eye of the patient leading to corneal re-epithelialization along with regression of both angiogenesis and persistent epithelial defects. This has subsequently led to the development and utilization of limbal stem cells grown on amniotic membrane as well as autologous mucosal epithelial cell grafts [108].

Previously, so called "wandering cells" were thought to play a part in tissue repair and wound healing. Recent stem cell research has revived this idea as reports point to similarities in the cornea. There is an increasing body of evidence suggesting that wandering cells are actually stem cells originating from the bone marrow, and can assist in tissue repair in various tissues including the cornea [81]. Recently a pioneer study demonstrated the migration of GFP-labeled BM-derived cells into the corneal stroma of mice [109]. It was shown immunohistochemically that some of the migrating cells were BM-derived dendritic

\footnotetext{
${ }^{\mathrm{c}}$ Blanco, T., Hutcheon, A.E.K., and Zieske, J.D. Up-Regulation of TGF- $\beta 1$ by $\alpha$ V $\beta 6$ Integrin Enhances Corneal Wound Healing in Mice. Program Summary of ARVO 2010 Meeting, Fort Lauderdale, Florida, May 2-16, 2010; p 172
} 
cells and macrophages [110]. The role of bone marrow-derived stem cells in corneal wound repair is an area with scant information that will benefit from thorough exploration.

In conclusion, TGF $\beta$ is a remarkable cytokine that plays a vital role in the homeostasis of all tissues in the human body including the cornea. It is essential for growth and development before birth and throughout life but can also lead to tissue failure and premature death if unregulated. Its different isoforms, biosynthesis, maturation, signal transduction involving the SMAD pathway, and biological function including its role in fibrosis and wound healing have been well documented. However, other signaling pathways have yet to be completely elucidated as it has become accepted that cross-talk is evident between pathways. In addition to regulating numerous other growth factors and cytokines, TGF $\beta$ is controlled not only by itself in a negative feedback manner, but also by other factors. Many of these factors, such as connective tissue growth factor, have been studied extensively but others have yet to be afforded the same attention. Importantly, TGF $\beta$ may hold the key to scarless tissue repair thus warranting further investigation. This is especially important in the cornea as TGF $\beta$ mediated corneal scarring is a leading cause of blindness. Effective treatment of fibrosis and scarring in the cornea is still under investigation as current modalities offer little resolution and are plagued with serious side effects. However, with continued research and the implementation of novel approaches such as targeted gene therapy and stem cell transplantation, the future seems bright in the field of corneal wound healing.

\section{Acknowledgments}

The work was supported by the RO1EY17294 (RRM) grant from the National Eye Institute, National Institutes of Health, Bethesda, MD and an unrestricted grant from the Research to Prevent Blindness, New York, NY.

\section{REFRENCES}

1. Chin D, Boyle GM, Parsons PG, Coman WB. Br J Plast Surg 2004;57:215-221. [PubMed: 15006522]

2. Assoian RK, Komoriya A, Meyers CA, Miller DM, Sporn MB. J. Biol. Chem 1983;258:7155-7160. [PubMed: 6602130]

3. De Larco JE, Todaro GJ. Proc. Nati Acad. Sci 1978;75:4001-4005.

4. Jester JV, Barry Lane PA, Petroll WM, Olsen DR, Cavanagh HD. Cornea 1997;16:177-187. [PubMed: 9071531]

5. Saika S. Cornea 2004;23:25-30.

6. Cordeiro MF. Prog Retin Eye Res 2002;21:75-89. Review. [PubMed: 11906812]

7. Attisano L, Wrana JL. Science 2002;296:1646-1647. [PubMed: 12040180]

8. Shi Y, Massague. J. Cell 2003;113:685-700.

9. Annes JP, Munger JS, Rifkin DB. J. Cell Sci 2003;116:217-224. [PubMed: 12482908]

10. Roberts AB. Miner Electrolyte Metab 1998;24:111-119. [PubMed: 9525693]

11. Wilson SE, Chen L, Mohan RR, Liang Q, Liu J. Exp Eye Res 1999;68:377-397. [PubMed: 10192796]

12. Imanishi J, Kamiyama K, Iguchi I, Kita M, Sotozono C, Kinoshita S. Prog Retin Eye Res 2000;19:113-129. [PubMed: 10614683]

13. Blobe GC, Schiemann WP, Lodish HF. N Engl J Med 2000;342:1350-1358. [PubMed: 10793168]

14. Sharma GD, He J, Bazan HE. J Biol Chem 2003;278:21989-21997. [PubMed: 12663671]

15. Saika S. Lab Invest 2006;86:106-115. [PubMed: 16341020]

16. Vij N, Sharma A, Thakkar M, Sinha S, Mohan RR. Mol Vis 2008;30:1020-1027. [PubMed: 18523665]

17. Kondaiah P, Sands MJ, Smith JM, Fields A, Roberts AB, Sporn MB, Melton DA. J Biol Chem 1990;265:1089-1093. [PubMed: 2295601] 
18. Cheifetz S, Hernandez H, Laiho M, ten Dijke P, Iwata KK, Massague J. J Biol Chem 1990;265:20533-20538. [PubMed: 1700790]

19. Tucker RF, Volkenant ME, Branum EL, Moses HL. Cancer Res 1983;43:1581-1586. [PubMed: 6299525]

20. Derynck R, Jarrett JA, Chen EY, Eaton DH, Bell JR, Assoian RK, Roberts AB, Sporn MB, Goeddel DV. Nature (London) 1985;316:701-705. [PubMed: 3861940]

21. Miyazono K. Blood 2008;112:3533-3544. [PubMed: 18948580]

22. Lu L, Reinach PS, Kao WW. Exp Biol Med (Maywood) 2001;226:653-664. [PubMed: 11444101]

23. Reneker LW, Bloch A, Xie L, Overbeek PA, Ash JD. Brain Res Bull. 2009

24. Karamichos D, Guo XQ, Hutcheon AE, Zieske JD. Invest Ophthalmol Vis Sci. 2010 (in press).

25. Saika S, Yamanaka O, Okada Y, Tanaka S, Miyamoto T, Sumioka T, Kitano A, Shirai K, Ikeda K. Front Biosci. (Schol Ed) 2009;1:376-390. [PubMed: 19482708]

26. Long Q, Chu R, Zhou X, Dai J, Chen C, Rao SK, Lam DS. J Refract Surg 2006;22:708-712. [PubMed: 16995554]

27. Kruse FE, Tseng SC. Ophthalmologe 1994;91:617-623. [PubMed: 7812093]

28. Koli K, Saharinen J, Hyytiainen M, Penttinen C, Keski-Oja J. Microsc. Res. Tech 2001;52:354362. [PubMed: 11170294]

29. Javelaud D, Mauviel A. The International Journal of Biochemistry \& Cell Biology 2004;36:11611165.

30. Houghton PE, Keefer KA, Krummel TM. Wound Repair Regen 1995;3:229-236. [PubMed: 17173652]

31. Wipff PJ, Hinz B. Eur J Cell Biol 2008;87:601-615. [PubMed: 18342983]

32. Massague J, Cheifetz S, Laiho M, Ralph DA, Weis FM, Zentella A. Cancer Surv 1992;12:81-103. [PubMed: 1638549]

33. Feng XH, Derynck R. Annu Rev Cell Dev Biol 2005;21:659-693. Review. [PubMed: 16212511]

34. Derynck R, Feng XH. Biochim Biophys Acta 1997;1333:F105-F150. [PubMed: 9395284]

35. Wieser R, Wrana JL, Massague J. EMBO J 1995;15:2199-2208. [PubMed: 7774578]

36. Franzen P, Heldin CH, Miyazono K. Biochem Biophys Res Commun 1995;15:682-689. [PubMed: 7864860]

37. Attisano L, Wrana JL, Cheifetz S, Massague J. Cell 1992;68:97-108. [PubMed: 1310075]

38. Wrana JL, Attisano L, Cárcamo J, Zentella A, Doody J, Laiho M, Wang XF, Massague J. Cell 1992;71:1003-1014. [PubMed: 1333888]

39. Segarini PR, Seyedin SM. J. Biol. Chem 1988;263:8366-8370. [PubMed: 2897367]

40. Lopez-Casillas F, Cheifetz S, Doody J, Andres JL, Lane WS, Massague J. Cell 1991;67:785-795. [PubMed: 1657406]

41. Lopez-Casillas F, Payne HM, Andres JL, Massague J. J. Cell Biol 1994;124:557-568. [PubMed: 8106553]

42. Cheifetz S, Bellon T, Cales C, Vera S, Bernabeu C, Massague J, Letarte M. J. Biol. Chem 1992;267:19027-19030. [PubMed: 1326540]

43. Laverty HG, Wakefield LM, Occleston NL, O'Kane S, Ferguson MW. 2009;20:305-317.

44. Nakao A, Imamura T, Souchelnytskyi S, Kawabata M, Ishisaki A, Oeda E, Tamaki K, Hanai J, Heldin CH, Miyazono K, Dijke P. EMBO J 1997;16:5353-5362. [PubMed: 9311995]

45. Kohei, Miyazono. Journal of Bone and Mineral Metabolism 1998;16:133-138.

46. Miyazono K, Kamiya Y, Morikawa M. J Biochem 2010;147:35-51. [PubMed: 19762341]

47. Heldin CH, Miyazono K, ten Dijke P. Nature 1997;390:465-471. [PubMed: 9393997]

48. Datto M, Wang XF. Cell 2005;8:2-4. [PubMed: 15820671]

49. Yingling JM, Datto MB, Wong C, Frederick JP, Liberati NT, Wang XF. Mol Cell Biol 1997;17:7019-7028. [PubMed: 9372933]

50. Chai J, Wu JW, Yan N, Massagué J, Pavletich NP, Shi Y. J Biol Chem 2003;30:20327-20331. [PubMed: 12686552] 
51. Vasilaki E, Siderakis M, Papakosta P, Skourti-Stathaki K, Mavridou S, Kardassis D. Biochemistry 2009;8:8366-8378. [PubMed: 19645436]

52. Itoh F, Divecha N, Brocks L, Oomen L, Janssen H, Calafat J, Itoh S, Dijke Pt P. Genes Cells 2002;7:321-331. [PubMed: 11918675]

53. Shi W, Chen H, Sun J, Chen C, Zhao J, Wang YL, Anderson KD, Warburton D. Am J Physiol Lung Cell Mol Physiol 2004;286:293-300.

54. Derynck R, Zhang YE. Nature 2003;425:577-584. Review. [PubMed: 14534577]

55. Bazan HE, Varner L. Curr Eye Res 1997;16:372-379. [PubMed: 9134327]

56. Li DQ, Luo L, Chen Z, Kim HS, Song XJ, Pflugfelder SC. Exp Eye Res 2006;82:588-596. [PubMed: 16202406]

57. Kretzschmar M, Doody J, Timokhina I, Massague J. Genes Dev 1999;13:804-816. [PubMed: 10197981]

58. Saarma M. Eur J Biochem 2000;267:6968-6971. [PubMed: 11106404]

59. Anumanthan G, Halder SK, Osada H, Takahashi T, Massion PP, Carbone DP, Datta PK. Br J Cancer 2005; 14:1157-1167. [PubMed: 16251876]

60. Bikfalvi A. Eur J Cancer 1995;31:1101-1104. [PubMed: 7577000]

61. Taipale J, Saharinen J, Keski-Oja J. Adv Cancer Res 1998;75:87-134. [PubMed: 9709808]

62. Li MO, Wan YY, Sanjabi S, Robertson AK, Flavell RA. Annu Rev Immunol 2006;24:99-146. [PubMed: 16551245]

63. Laiho M, Saksela O, Keski-Oja J. J Biol Chem 1987;262:17467-17474. [PubMed: 3121597]

64. Streuli CH, Schmidhauser C, Kobrin M, Bissell MJ, Derynck R. J Cell Biol 1993;120:253-260. [PubMed: 8416992]

65. Shah RM, Friedman AC, Ostrum BJ, Sexauer W, Fiel SB. Crit Rev Diagn Imaging 1995;36:441477. Review. [PubMed: 8785013]

66. Longaker MT, Adzick NS. Plast Reconstr Surg 1991;87:788-798. [PubMed: 2008482]

67. Werner S, Grose R. Physiol Rev 2003;83:835-870. [PubMed: 12843410]

68. Singer AJ, Thode HCJ, McClain SA. Acad Emerg Med 2000;7:1083-1088. [PubMed: 11015238]

69. Martin P, Parkhurst SM. Development 2004;131:3021-3034. [PubMed: 15197160]

70. Whitby DJ, Ferguson MW. Dev Biol 1991;147:207-215. [PubMed: 1879607]

71. Bullard KM, Longaker MT, Lorenz HP. World J. Surg 2003;27:54-61. [PubMed: 12557038]

72. O'Kane S, Ferguson MW. Int J Biochem Cell Biol 1997;29:63-78. [PubMed: 9076942]

73. Krummel TM, Michna BA, Thomas BL, Sporn MB, Nelson JM, Salzberg AM, Cohen IK, Diegelmann RF. J Pediatr Surg 1988;23:647-652. [PubMed: 3204464]

74. August P, Suthanthiran M. N Engl J Med 2006;354:2721-2723. [PubMed: 16790709]

75. Reiss M. Microbes Infect 1999;1:1327-1347. [PubMed: 10611761]

76. Wrzesinski SH, Wan YY, Flavell RA. Clin Cancer Res 2007;13:5262-5270. [PubMed: 17875754]

77. Konigshoff M, Kneidinger N, Eickelberg O. Swiss Med Wkly 2009;139:554-563. [PubMed: 19838873]

78. Bujak M, Frangogiannis NG. Cardiovasc Res 2007;74:184-195. [PubMed: 17109837]

79. Wilson SE, Schultz GS, Chegini N, Weng J, He YG. Exp Eye Res 1994;59:63-71. [PubMed: 7530663]

80. Huh MI, Chang Y, Jung JC. Histol Histopathol 2009;24:1405-1416. [PubMed: 19760590]

81. Fini ME, Stramer BM. Cornea 2005;24:S2-S11. [PubMed: 16227819]

82. Nishida K, Kinoshita S, Yokoi N, Kaneda M, Hashimoto K, Yamamoto S. Invest Ophthalmol Vis Sci 1994;35:3289-3294. [PubMed: 8045718]

83. Pasquale LR, Dorman-Pease ME, Lutty GA, Quigley HA, Jampel HD. Invest Ophthalmol Vis Sci 1993;34:23-30. [PubMed: 8425829]

84. Stramer BM, Zieske JD, Jung JC, Austin JS, Fini ME. Invest Ophthalmol Vis Sci 2003;44:42374246. [PubMed: 14507867]

85. Nakamura K, Kurosaka D, Bissen-Miyajima H, Tsubota K. Br J Ophthalmol 2001;85:209-213. [PubMed: 11159488] 
86. Jester JV, Barry-Lane PA, Cavanagh HD, Petroll WM. Cornea 1996;15:505-516. [PubMed: 8862928]

87. Strissel KJ, Rinehart WB, Fini ME. Invest Ophthalmol Vis Sci 1995;36:151-162. [PubMed: 7822142]

88. Foster A, Resnikoff S. Eye 2005;19:1133-1135. [PubMed: 16304595]

89. Jester JV, Petroll WM, Cavanagh HD. Prog Retin Eye Res 1999;18:311-356. [PubMed: 10192516]

90. Chang Y, Wu XY. J Int Med Res 2009;37:727-736. [PubMed: 19589256]

91. Padua D, Massague J. Cell Research 2009;19:89-102. [PubMed: 19050696]

92. Liu W, Wang DR, Cao YL. Curr Gene Ther 2004;4:123-136. [PubMed: 15032619]

93. Masur SK, Dewal HS, Dinh TT, Erenburg I, Petridou S. Proc Natl Acad Sci 1996;93:4219-4223. [PubMed: 8633044]

94. Price FW Jr, Willes L, Price M, Lyng A, Ries J. Ophthalmology 2001;108:1236-1245. [PubMed: $11425681]$

95. Nassaralla BA, McLeod SD Jr, Nassaralla JJ. J Refract Surg 2007;23:226-232. [PubMed: 17385287]

96. Nassiri N, Farahangiz S, Rahmani L, Nassiri N. J Cataract Refract Surg 2008;34:902-908. [PubMed: 18498993]

97. Netto MV, Mohan RR, Sinha S, Sharma A, Gupta PC, Wilson SE. J. Refractive Surg 2006;22:562574.

98. Chang JH, Kook MC, Lee JH, Chung H, Wee WR. Exp Eye Res 1998;66:389-396. [PubMed: 9593632]

99. Bilgihan K, Ozdek S, Ozogul C, Gurelik G, Bilgihan A, Hasanreisoglu B. Eye 2000;14:231-237. [PubMed: 10845023]

100. Nassaralla BA, Szerenyi K, Wang XW, Reaves T, McDonnell PJ. Opthalmol 1995;102:469-474.

101. Cellini M, Bendo E, Bravetti GO, Campos EC. Ophthalmic Res 2006;38:177-181. [PubMed: 16679804]

102. Arora R, Mehta D, Jain V. Eye 2005;19:273-278. [PubMed: 15286672]

103. Sharma A, Mehan MM, Cowden JW, Mohan RR. Invest. Ophthalmol Vis Sci 2009;50:26952701. [PubMed: 19168895]

104. Mohan RR, Sharma A, Netto MV, Sinha S, Wilson SE. Prog Retin Eye Res 2005;24:537-559. [PubMed: 15955719]

105. Mohan RR, Gupta R, Mehan MM, Cowden JW, Wilson SE, Sinha S. Exp Eye Res. 2010 (in press).

106. Shah M, Foreman DM, Ferguson MW. Lancet 1992;25:213-214. [PubMed: 1346175]

107. Carrington LM, Albon J, Anderson I, Kamma C, Boulton M. Invest Ophthalmol Vis Sci 2006;47:1886-1894. [PubMed: 16638995]

108. Secker GA, Daniels JT. Stem Cell Rev 2008;4:159-168. [PubMed: 18622724]

109. Wilson SE, Mohan RR, Netto M, Perez V, Possin D, Huang J, Kwon R, Alekseev A, RodriguezPerez JP. Invest Ophthalmol Vis Sci 2004;45:2201-2211. [PubMed: 15223796]

110. Nakamura T, Ishikawa F, Sonoda KH, Hisatomi T, Qiao H, Yamada J, Fukata M, Ishibashi T, Harada M, Kinoshita S. Invest Ophthalmol Vis Sci 2005;46:497-503. [PubMed: 15671274] 


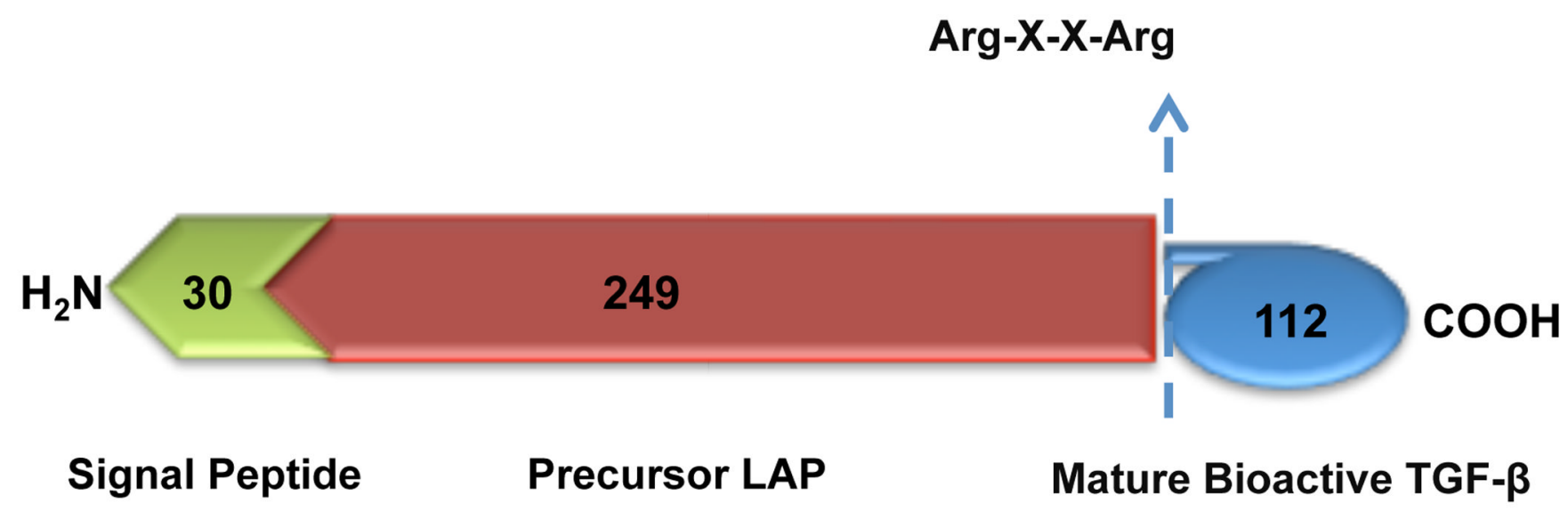

Fig. (1).

Schematic representation of the protein structure related to TGF $\beta$. An N-terminal hydrophobic signal peptide region (30 amino acids), the latent associated peptide (LAP) (249 amino acids) region and the C-terminal, a mature bioactive TGF $\beta$ region. 


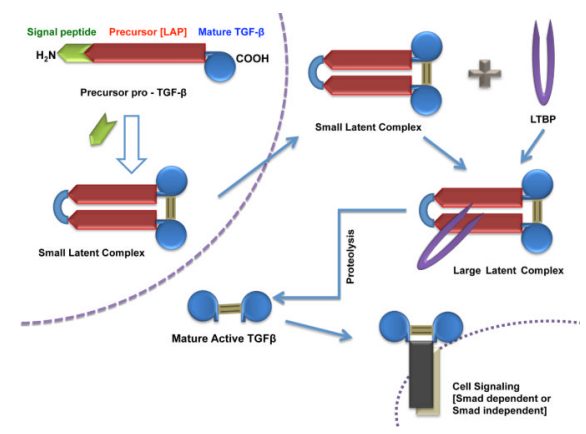

Fig. (2).

Schematic representation of TGF $\beta$ maturation. Precursor pro-TGF $\beta$ is cleaved by endopeptidase in Golgi apparatus to form small latent complex. This complex then covalently binds with latent TGF $\beta$ binding protein (LTBP) and forms the large latent complex that is finally released into the ECM as mature TGF $\beta$. 


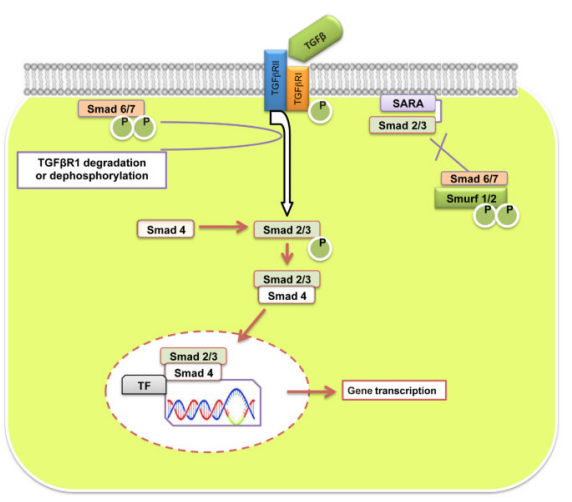

Fig. (3).

TGF $\beta$ Smad-dependent signaling pathway: TGF $\beta$ exerts its effect by binding and activating type II receptor (TGF $\beta R 2$ ) and then type I receptor (TGF $\beta R 1)$. After phosphorylation, TGF $\beta R 2$ phosphorylates TGF $\beta$ R 1 , which subsequently phosphorylates and activates RSmads (Smad2/3). Activated R-Smads are released from receptors then form a heterotrimeric complex with co-Smad $(\mathrm{Smad} 4)$, which is translocated into the nucleus to regulate transcription of the target gene. I-Smads (Smad6 and Smad7) shows inhibitory Smad interaction and interfere with the activation of R-Smads while Smurf1/2 targets TGFßR-1 and TGFßR-2 along with various Smad family proteins for proteasome-mediated degradation. 


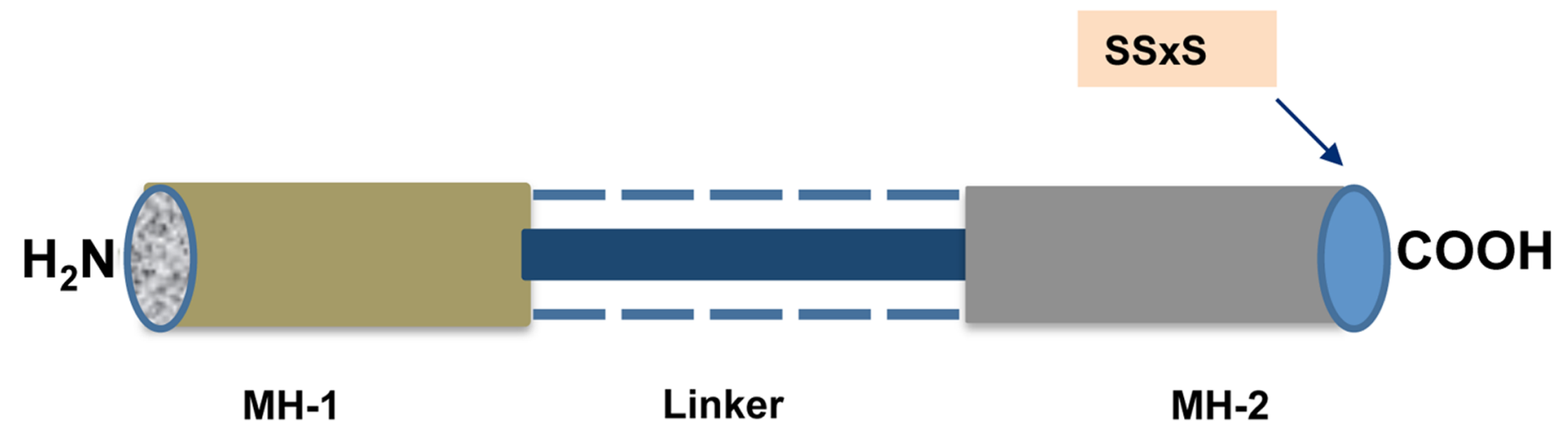

Fig. (4).

Schematic diagram of R-Smad containing MH-1 and MH-2 regions at amino (N) and carboxyl (C) terminal respectively linked together by variable linker region and specific phosphorylation motif, SSxS, at C-terminus. 


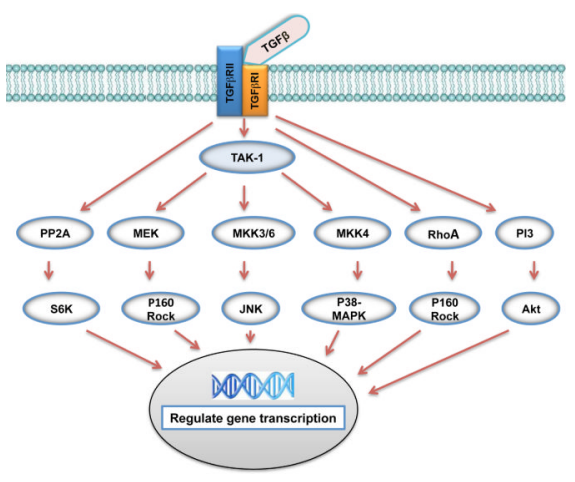

Fig. (5).

TGF $\beta$ Smad-independent Signaling Pathways: TGF $\beta$ exerts its effect by binding and activating type II receptor (TGF $\beta$ R2) and then type I receptor (TGF $\beta R 1)$. Smad independent pathways are then activated and include various branches of MAP kinase (MAPK) pathways, Rho-like GTPase signaling pathways, phosphatidylinositol-3-kinase (PI3K)/AKT pathways and protein phosphatase 2A (PP2A) pathway. These pathways then regulate gene transcription in the nucleus. The exact mechanism of activation of these various Smadindependent signaling pathways remains to be elaborated. 

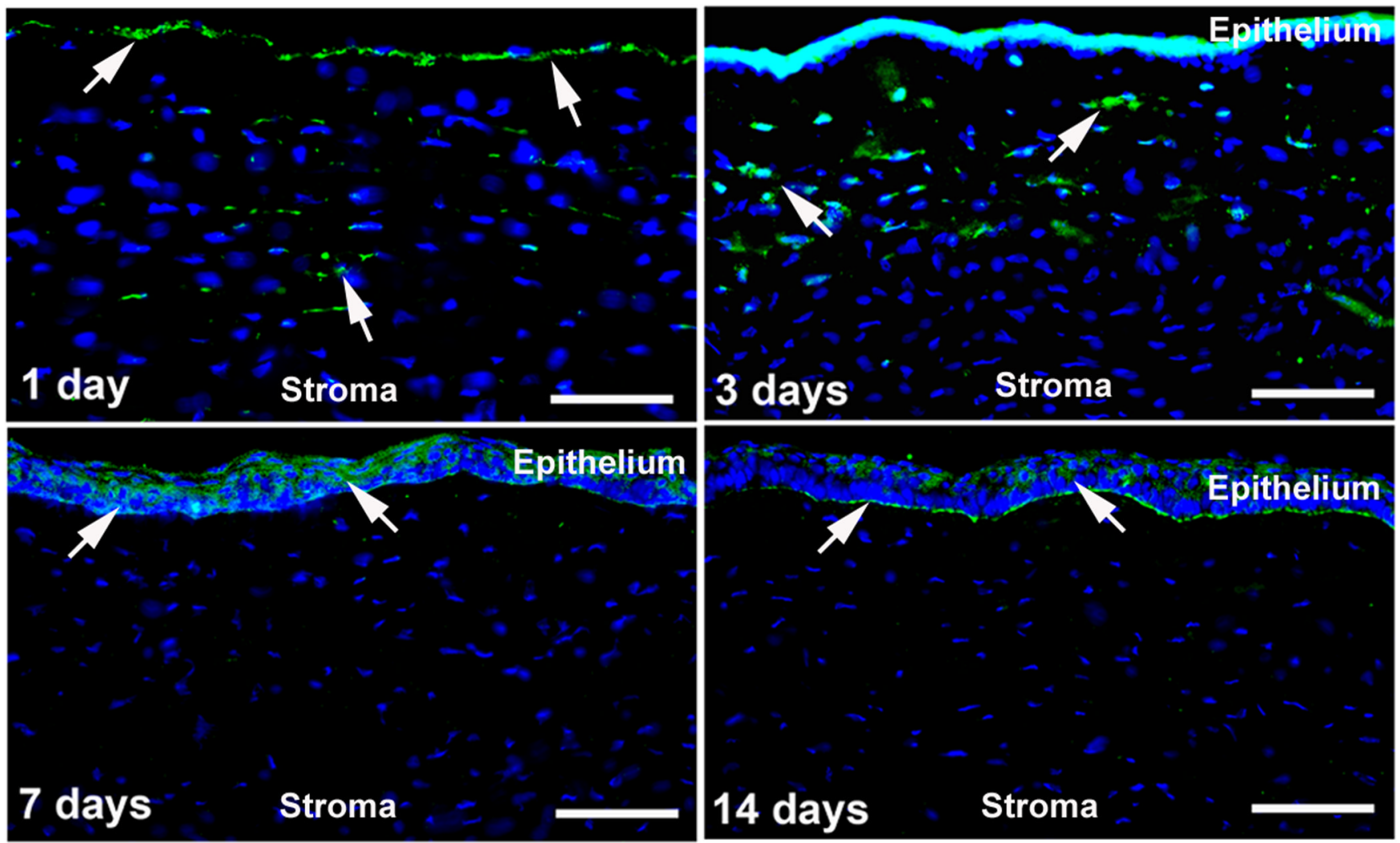

Fig. (6).

Representative immunofluorescence images showing time-dependent expression and localization of TGF $\beta 1$ in -9.0 D PRK-treated rabbit cornea. PRK caused a significant increase in TGF $\beta 1$ in the stroma at day 1 and day $3(\mathrm{p}<0.001$ or $<0.01)$ compared to naïve corneas. The elevated level of TGF $\beta 1$ showed progressive decline as extremely low or no expression was detected at day 7 or day 14 in the stroma. The naïve corneas did not show any TGF $\beta 1$ expression (data not shown). Scale bar denotes $50 \mu \mathrm{m}$. 

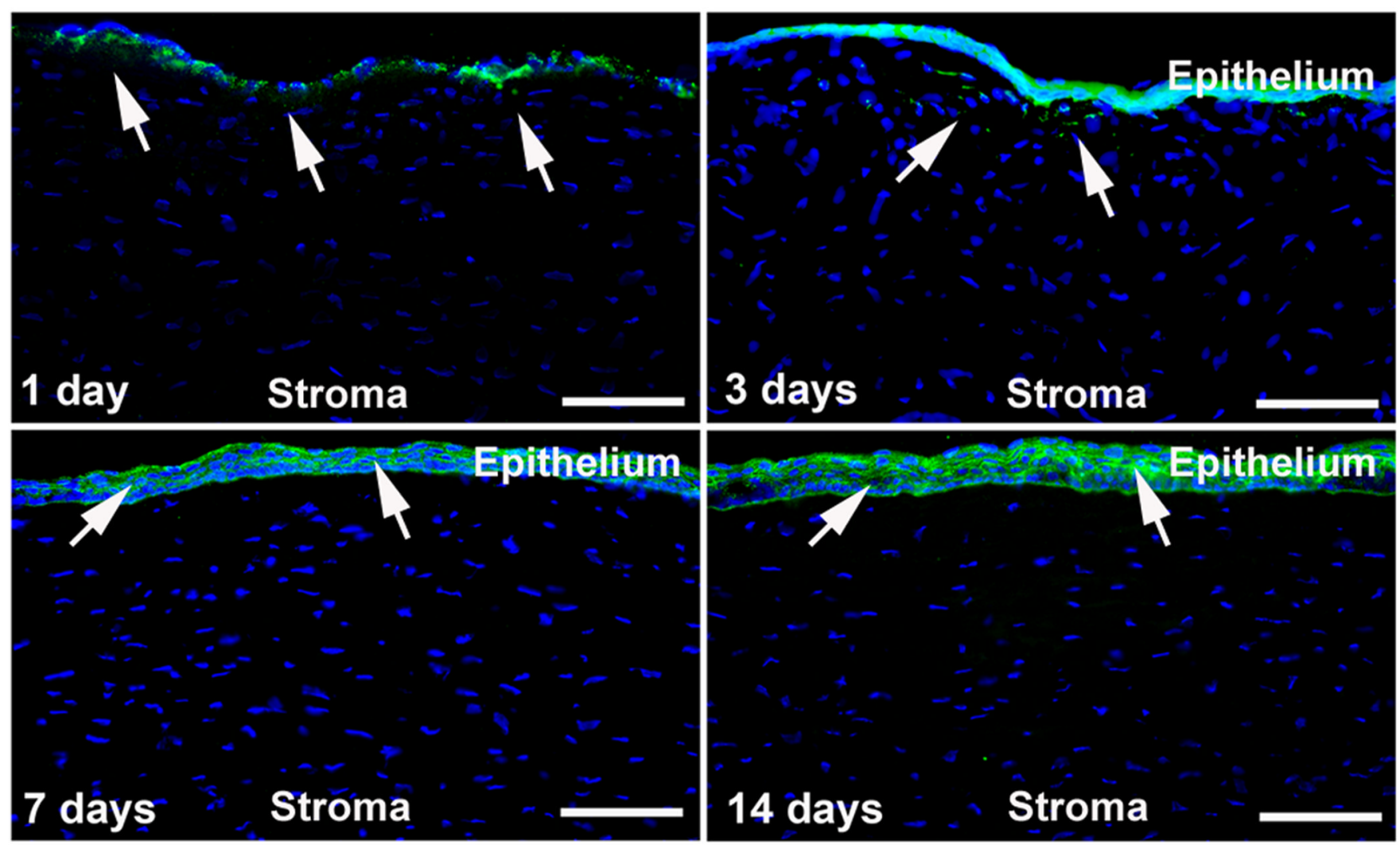

7 days

\section{Stroma}

Fig. (7).

Representative immunofluorescence images showing time-dependent expression and localization of TGF $\beta 2$ in -9.0 D PRK-treated rabbit cornea. PRK induced TGF $\beta 2$ expression in the stroma at an early time points (day 1 and day 3 ) as no expression of TGF $\beta 2$ was detected in naïve corneas (data not shown). Scale bar denotes $50 \mu \mathrm{m}$. 


\begin{tabular}{|c|c|c|c|c|}
\hline \multirow{3}{*}{$\begin{array}{l}\underset{\Xi}{E} \\
\frac{0}{0} \\
\stackrel{0}{\sigma}\end{array}$} & 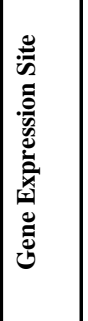 & 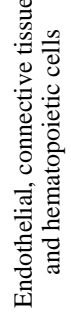 & 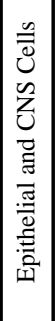 & 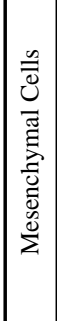 \\
\hline & 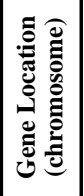 & $\frac{m}{\sigma}$ & $\underset{\Xi}{F}$ & 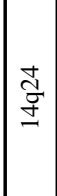 \\
\hline & 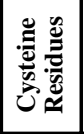 & $m$ & 0 & in \\
\hline \multirow{4}{*}{ 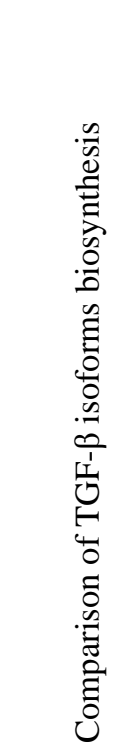 } & 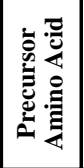 & ஓ్ & 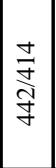 & $\stackrel{\ominus}{\gamma}$ \\
\hline & 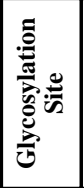 & $m$ & $m$ & + \\
\hline & 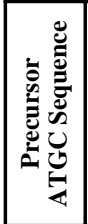 & $\begin{array}{l}\frac{5}{0} \\
\frac{0}{2} \\
0 \\
0\end{array}$ & 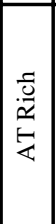 & 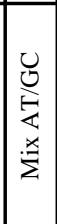 \\
\hline & 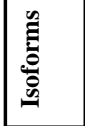 & $\begin{array}{l}\overrightarrow{0} \\
\overrightarrow{5} \\
\overrightarrow{5}\end{array}$ & 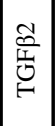 & 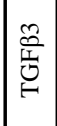 \\
\hline
\end{tabular}

